\title{
Conceptual Design of Pedestrian Overpasses Bridge for Vertical Evacuation from Tsunami (POBET) in Padang City - West Sumatra
}

\author{
Andi Syukri, Gusri Yaldi, Desmon Hamid, Lukman Murdiansyah, Aufaa Rozaan, Afrina Roza \\ Jurusan Teknik Sipil, Politeknik Negeri Padang \\ E-mail: syukri.andinesia@gmail.com, gusri.yaldi@gmail.com, desmon hamid@yahoo.co.uk, \\ lukman murdiansyah@yahoo.com, aufaa.rozaan@gmail.com, afrinaroza77@yahoo.com
}

\begin{abstract}
Padang City, the most populated city in West Sumatra, is considered to have one of the world's highest tsunami risks due to its high and close offshore thrust-fault seismic hazard, its flat terrain, and its dense population, which is mostly distributed along the coast. Current preparation for a tsunami in Padang focuses on developing early warning systems, planning evacuation routes, conducting evacuation drills, and educating the public about its tsunami risk. These are necessary, but insufficient, steps. The natural warning in Padang — strong earthquake shaking that lasts over a minute — will be the first and best indicator that a tsunami is likely to strike. It is estimated that even if evacuation begins immediately after the earthquake shaking stops, more than 100,000 inhabitants of Padang will be unable to reach high ground in less than 30 minutes-the expected time between the end of the earthquake shaking and the arrival of the tsunami wave at the shore. Based on Evaluation of Tsunami Evacuation Infrastructure for Padang, West Sumatra, Indonesia (Veronica, et.al: 2011) concluded, based upon extensive fieldwork, that Padang's existing tsunami evacuation capacity is grossly inadequate, and that tsunami evacuation structures are essential to protect the people of Padang. To maximize their impact and effectiveness, those tsunami evacuation structures should be locally-appropriate, feasible to build and maintain, and easy to replicate. The M7.6 earthquake that struck Padang on September 30, 2009 confirmed this critical need for tsunami evacuation infrastructure. Although the earthquake did not generate a tsunami, it did cause the collapse of many buildings that had previously been identified as satisfactory evacuation structures. The earthquake also triggered massive traffic jams, stranding people in harm's way and demonstrating why Padang needs structures that enable more people to evacuate-in-place. Finally, it needs to design new structures to accommodate people to evacuate immediately in place. Pedestrian Overpasses Bridge for Vertical Evacuation from Tsunami (POBET) will work effectively for evacuees who get traffic jam during the tsunami inundated elapsed critical hours. The most reason for POBET need to be design is a prototype for the government to combine pedestrian overpasses bridge with vertical evacuation from tsunami. These evacuation infrastructures consider about less for land use, easy to reach, compatible for any infrastructure purposes. Rely on budget and planning, POBET would design with a smallest amount budget and effortless construction process. It can be replicate by the local government to build in any place in Padang City.
\end{abstract}

Keywords : Tsunami risk; Vertical Evacuation; Bridge; Infrastructure.

\section{INTRODUCTION}

Pedestrian Overpasses Bridge for Vertical Evacuation from Tsunami (POBET) is developed into structural and function into a shelter from tsunami. Optimizing public facilities as domain work as originally constructed just for pedestrian overpass the traffic. Existing vertical evacuation buildings in Padang is inadequate to accommodate community who live in vulnerable zone (1 $\mathrm{km}$ from shorelines). Land availability, high cost, maintenance, functioning, and replication structure as the main obstacle to construct the vertical evacuation buildings in Padang. POBET is indicated as alternative remark for vertical evacuation infrastructure in Padang City, West Sumatra Indonesia.
Based on observation, Padang City is the highest vulnerable city in the world due to the tsunami impact [12] It relies on the high density of community who live in coastal area. Horizontal evacuation route does not accommodate peoples to evacuate in land in the remaining time. Traffic bottle neck is triggered by evacuee behavior using vehicle to evacuate in land. Pedestrian Overpasses Bridge in the main road of Padang City do not optimize well in the recent decade. Most of the Pedestrian Overpasses Bridge is lack of structure adequacy because of steel corrosion and pedestrian do not have awareness in safety for crossing the road. Then, A numerous of traffic road in Padang is parallel with coastline and make vulnerable zone in several area where does not have perpendicular routes from the coastal line [3]. 


\section{MAterial AND METHOdOlogy}

Conceptual Design of POBET is one of phases POBET frame work Prototype. This is a preliminary process for designing of POBET as vertical evacuation structure. Methodology for Conceptual Design of POBET is considered in 4 (four) phase, there are 1).Vulnerability Desk Study; 2).Field Investigation; 3).Architectural and Structural Design Consideration; 4).Cost Estimation.

\section{A. Vulnerability Desk Study}

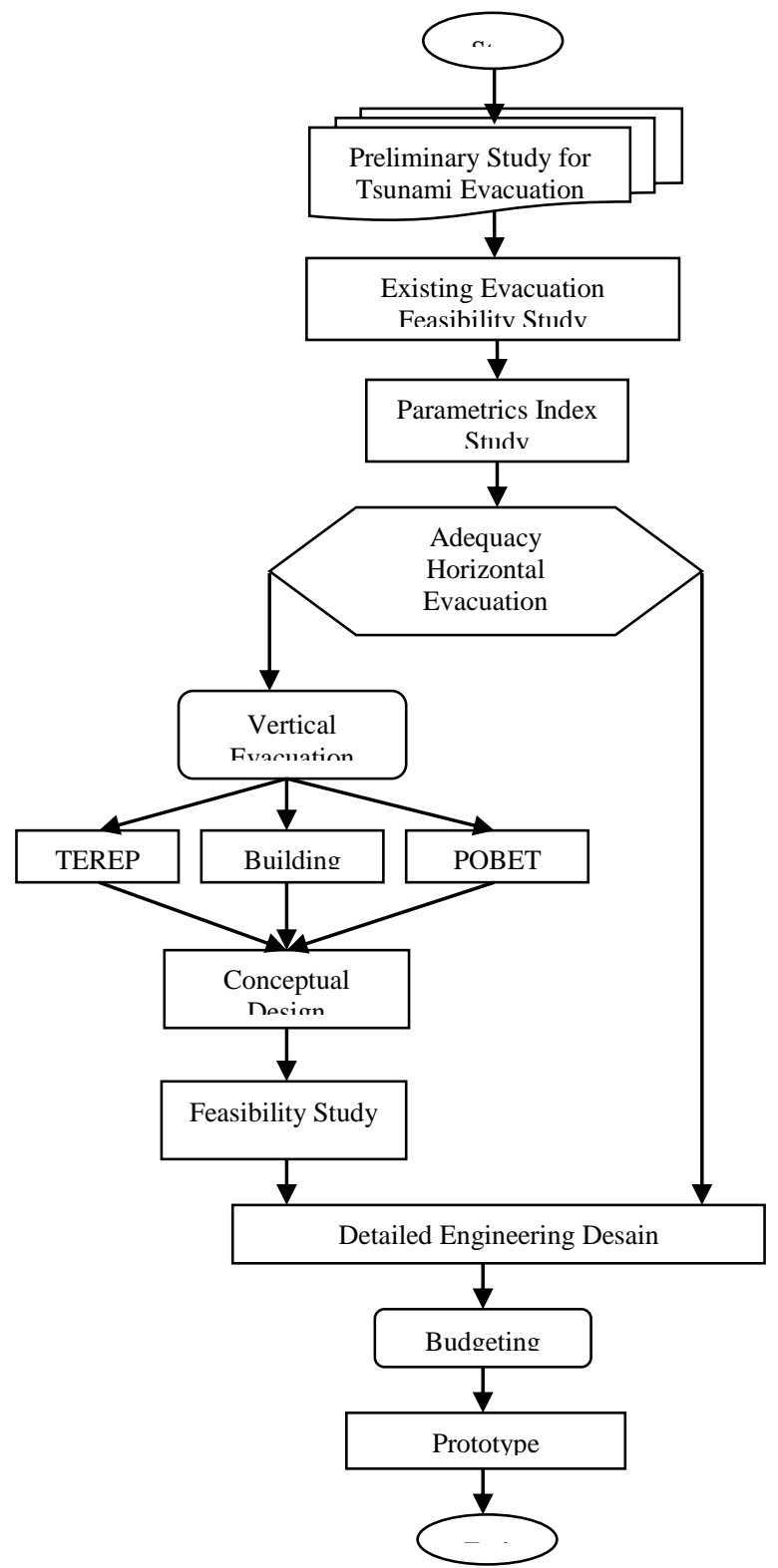

Fig.1 Road Map for Research of Vertical Evacuation from Tsunami
Desk Study of POBET is refers to Tsunami Inundation Map Consensus 2011 [2] that demonstrates the vulnerable zone regarding to run up tsunami in Padang City based on worst scenarios. Regarding to geographic condition, Inundation map will overlay with satellite data that produce with Google map to indicate vulnerability for traffic routes, estimated travel time, affected zone and estimated density area.

Demographic study will refer to Badan Pusat Statistik (Statistic Central Data Boards) of Padang City to observe people density, building data, and length of roads. Vulnerable desk study will considered about vulnerable map (BPBD Padang, 2010) and Tsunami and Earthquake Zone in Padang City (BMKG, 2010) to observe designated horizontal evacuation routes from Tsunami in Padang City.

POBET vulnerability parameters for tsunami is considering about location, buildings, social, infrastructure, shelters, and accessibility. Location vulnerability will indicate about buildings plan and coordinates for candidates of POBET by using Google earth application to estimate location and affected area would be accommodated by POBET. Buildings vulnerability will consider about distance from shoreline and riverside. Minimum distance from is approximate 1 $\mathrm{km}$ far from coastline. Parameters is used to identify the buildings candidate for POBET will be indexed to measure the vulnerability based on,

1. Location
a. Buildings planning
b. Buildings coordinates

2. Buildings
a. Inundation
b. Distance from shoreline and riverside

3. Social
a. People density in region/village
b. People density by gender
c. People density by age

4. Infrastructure
a. School in every village
b. Medical Facilities 
c. Religion Facilities

d. Public Facilities

5. Shelter availability

6. Accessibility
a. Number of Road
b. Public facility
c. Public transport

Those parametric will be indexed by table I [1]

TABLE I

VULNERABILITY INDEX FOR EVACUATION

\begin{tabular}{|c|c|c|c|c|c|c|}
\hline $\mathbf{N}$ & \multirow{2}{*}{ Parameter } & \multicolumn{5}{|c|}{ Index } \\
\hline . & & 5 & 4 & 3 & 2 & 1 \\
\hline \multicolumn{7}{|c|}{ Location $(\mathrm{km})$} \\
\hline A & $\begin{array}{l}\text { Inundation } \\
\text { Distance }\end{array}$ & $0-0.5$ & $0.5-1$ & $1-1.5$ & $1.5-2$ & $>2$ \\
\hline $\mathrm{B}$ & $\begin{array}{l}\text { Shorline } \\
\text { Distance }\end{array}$ & $0-0.5$ & $0.5-1$ & $1-1.5$ & $1.5-2$ & $>2$ \\
\hline $\mathrm{C}$ & $\begin{array}{l}\text { Riverside } \\
\text { Distance }\end{array}$ & $0-0.5$ & $0.5-1$ & $1-1.5$ & $1.5-2$ & $>2$ \\
\hline$D$ & Inundation & $>2$ & $1.5-2$ & $1-1.5$ & $0.5-1$ & $\begin{array}{l}0- \\
0.5\end{array}$ \\
\hline \multicolumn{7}{|c|}{ People Density (people) } \\
\hline $\mathrm{E}$ & District & $\begin{array}{c}>1000 \\
00\end{array}$ & $\begin{array}{l}7500- \\
10000\end{array}$ & $\begin{array}{l}5000- \\
7500\end{array}$ & $\begin{array}{c}2500- \\
5000\end{array}$ & $\begin{array}{c}0- \\
2500\end{array}$ \\
\hline $\mathrm{F}$ & Male & $\begin{array}{l}0- \\
300\end{array}$ & $\begin{array}{c}300- \\
600 \\
\end{array}$ & $\begin{array}{c}600- \\
900 \\
\end{array}$ & $\begin{array}{l}900- \\
1200 \\
\end{array}$ & $\begin{array}{c}>120 \\
0\end{array}$ \\
\hline G & Female & $>1200$ & $\begin{array}{l}900- \\
1200 \\
\end{array}$ & $\begin{array}{c}600- \\
900 \\
\end{array}$ & $\begin{array}{c}300- \\
600 \\
\end{array}$ & $\begin{array}{l}0- \\
300 \\
\end{array}$ \\
\hline \multirow[t]{5}{*}{$\mathrm{H}$} & \multicolumn{6}{|c|}{ Age Composition } \\
\hline & a. Infant & $\begin{array}{l}0- \\
100 \\
\end{array}$ & $\begin{array}{l}100- \\
200\end{array}$ & $\begin{array}{l}200- \\
300\end{array}$ & $\begin{array}{c}300- \\
400\end{array}$ & $>400$ \\
\hline & b. Adult & $>400$ & $\begin{array}{c}300- \\
400\end{array}$ & $\begin{array}{c}200- \\
300\end{array}$ & $\begin{array}{l}100- \\
200 \\
\end{array}$ & $\begin{array}{l}0- \\
100 \\
\end{array}$ \\
\hline & c. Old & $\begin{array}{l}0- \\
100 \\
\end{array}$ & $\begin{array}{l}100- \\
200 \\
\end{array}$ & $\begin{array}{c}200- \\
300 \\
\end{array}$ & $\begin{array}{c}300- \\
400 \\
\end{array}$ & $>400$ \\
\hline & d. Resident & $\begin{array}{l}0- \\
100 \\
\end{array}$ & $\begin{array}{l}100- \\
200 \\
\end{array}$ & $\begin{array}{c}200- \\
300 \\
\end{array}$ & $\begin{array}{c}300- \\
400 \\
\end{array}$ & $>400$ \\
\hline \multicolumn{7}{|c|}{ Facilities (unit) } \\
\hline 1 & Education & $>10$ & $9-10$ & $6-8$ & $3-5$ & $0-4$ \\
\hline $\mathrm{J}$ & Religion & $>24$ & $\begin{array}{c}18- \\
24 \\
\end{array}$ & $\begin{array}{c}13- \\
18 \\
\end{array}$ & $12-7$ & $0-6$ \\
\hline $\mathrm{K}$ & Health & $>20$ & $\begin{array}{c}15- \\
20\end{array}$ & $\begin{array}{c}15- \\
10\end{array}$ & $10-5$ & $0-5$ \\
\hline $\mathrm{L}$ & Others & $>1000$ & $\begin{array}{c}1000- \\
750\end{array}$ & $\begin{array}{l}750- \\
500\end{array}$ & $\begin{array}{c}500- \\
250\end{array}$ & $\begin{array}{c}0- \\
250\end{array}$ \\
\hline \multicolumn{7}{|c|}{ Shelter availability $(\mathrm{km})$} \\
\hline M & $\begin{array}{l}\text { Vertical } \\
\text { Evacuation }\end{array}$ & $>2$ & $1,5-2$ & $1-1,5$ & $0,5-1$ & $\begin{array}{l}0- \\
0,5\end{array}$ \\
\hline $\mathrm{N}$ & $\begin{array}{l}\text { Horizontal } \\
\text { Evacuation }\end{array}$ & $>2$ & $1,5-2$ & $1-1,5$ & $0,5-1$ & $\begin{array}{l}0- \\
0,5\end{array}$ \\
\hline \multirow[t]{3}{*}{$\mathrm{O}$} & \multicolumn{6}{|c|}{ Eavcuation Travel time (minute) } \\
\hline & a. Vehicle & $\begin{array}{c}32- \\
40\end{array}$ & $\begin{array}{c}24- \\
32 \\
\end{array}$ & $\begin{array}{l}16- \\
24\end{array}$ & $8-16$ & $0-8$ \\
\hline & b. Walking. & $\begin{array}{c}120- \\
150 \\
\end{array}$ & $\begin{array}{l}90- \\
120 \\
\end{array}$ & $\begin{array}{l}60- \\
90 \\
\end{array}$ & $\begin{array}{c}30- \\
60 \\
\end{array}$ & $0-30$ \\
\hline $\mathrm{P}$ & \multicolumn{6}{|c|}{ Evacuation Routes Capacity } \\
\hline & $\begin{array}{l}\text { a. Number of } \\
\text { route }\end{array}$ & $0-2$ & $3-4$ & $5-6$ & $7-8$ & $>8$ \\
\hline & $\begin{array}{l}\text { b. Distance of } \\
\text { route }\end{array}$ & $>0,8$ & $\begin{array}{c}0,8- \\
0,6\end{array}$ & $\begin{array}{c}0,6- \\
0,4\end{array}$ & $\begin{array}{c}0,4- \\
0,2 \\
\end{array}$ & $\begin{array}{c}0,2- \\
0\end{array}$ \\
\hline & $\begin{array}{l}\text { c. Number of } \\
\text { public } \\
\text { transport }\end{array}$ & $>8$ & $6-7$ & $5-6$ & $3-4$ & $0-2$ \\
\hline
\end{tabular}

These vulnerability indexes are applied to 3 (three) candidate locations for POBET in Padang City, West Sumatra, they are,

1. Bagindo Azis Chan intersection, South Padang District

2. Jati Intersection, East Padang District

3. Tunggul Hitam, North Padang District

\section{B. Field Investigation}

Field investigation is to gain traffic data in designated area about to measure location, traffic observation in intersection and two ways road. This activity will contribute for intersection behavior data, intersection bottle neck condition, and dimension of location for POBET. Intersection investigation for POBET consider about geometric, traffic condition, and pedestrian behavior. Parametric of pedestrian will influence geometric and capacity of pedestrian overpasses bridge. It needs to investigate pedestrian characteristic for designing POBET as a overpasses facilities. It is based on code of Land Transportation General Directorate No. SK.43/AJ/007/DRJD/97 [16].

Identify candidate for tsunami evacuation structures by extracting facilities located in a tsunami inundation area which satisfy the structural requirements. In addition, dtermine the area covered by each candidate bulding based on the relationshio between the achievable evacuation range and achievable accomodation range. Select candidate for tsunami evacuation structure in a manner that ensure all difficult to evacuate areas are covered by those candidates [5]. For this purposes perform

1. Selection of candidates for tsunami evacuation structures

2. Estimation of the range within which evacuatin to each candidate for tsunami evacuation structure would be achievable

3. Estimation of the range commensurate with the capacity of each candidate for tsunami evacuation buildings

4. Specification of a coverage area 


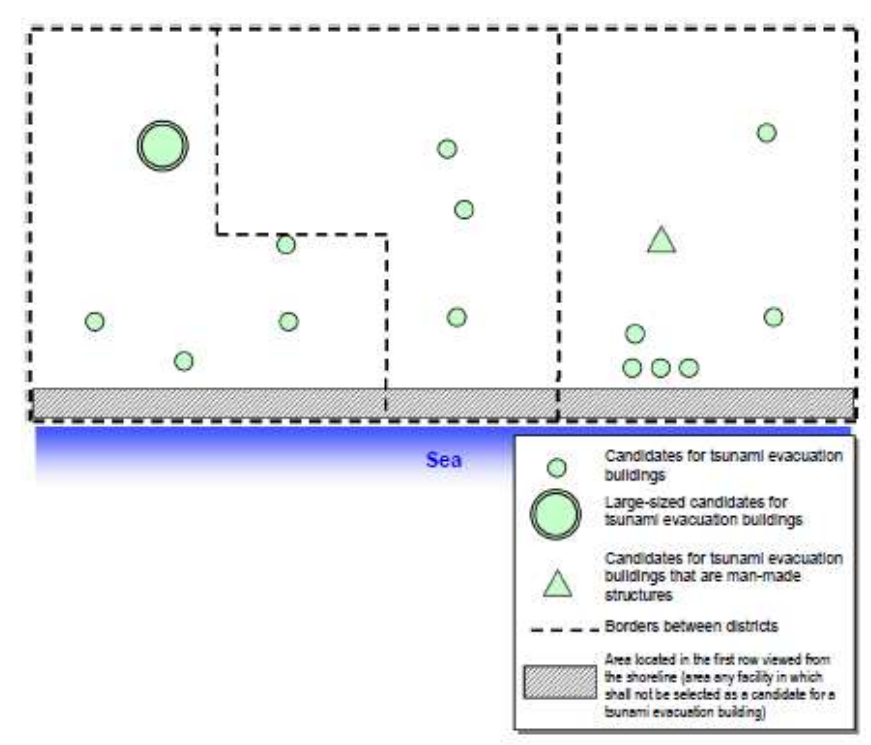

Fig.2 Image of the extracion of candidates for tsunami evacuation buildings

Estimate the range allowing the accomodation, which has a population equivalent to the number of people who will be accomodated, as calculated the distance allowing accomodation (L2) (semicircle)

$$
L 2=\sqrt{\frac{\text { Capcity(person)/Population_Density }}{3.14} \times 4}
$$

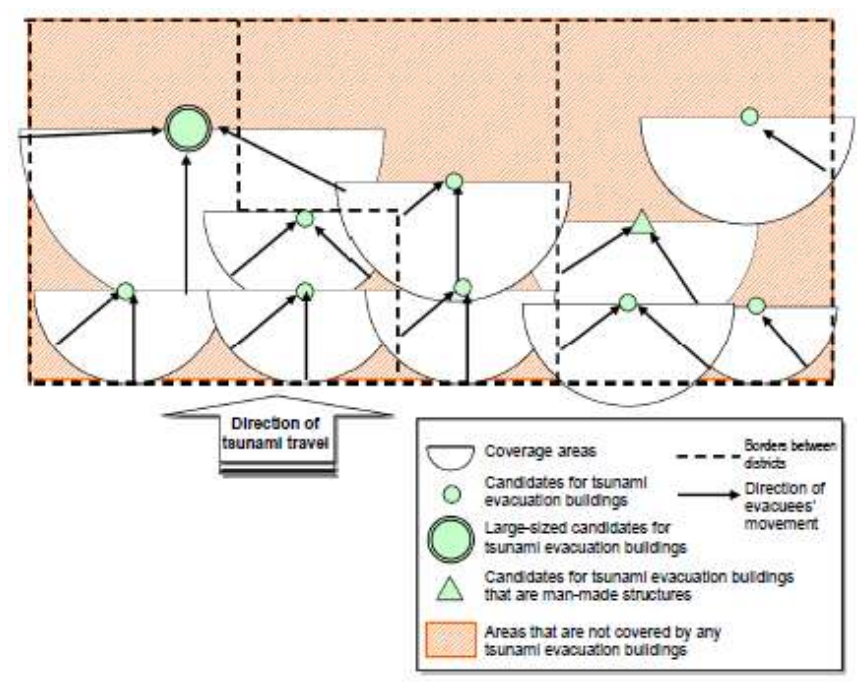

Fig. 3 Image of the selection of candidates for tsunami evacuation buildings

\section{Architectural and Structural Design Consideration}

As the main function, POBET is designed as pedestrian overpasses bridge and vertical evacuation from tsunami. Based on Code of Pedestrian Overpasses Bridge of Public Work No.027/Bt/T/1995, Pedestrian Overpasses Bridge is a complement building above the road or railway to overpasses the pedestrian. Then, based on FEMA P646 [3] vertical evacuation from tsunami is an evacuation method to walk inland if tsunami is occurred.

POBET is a reinforced concrete bridge. Regarding to RSNI T-12-2004, Reinforced Concrete Bridge is a bridge with concrete as main material that is made from Portland cement, aggregates and water and reinforced with steel bar in structural design requirement [17]. The main reason pedestrian overpasses bridge convert to POBET is based on general requirement of Public Work (1995).

\section{Design Basic}

POBET as Pedestrian Overpasses Bridge in city consider any factors. They are easy to construct, less traffic disturbance, require for driver safety passed underneath the bridge and less maintenance. Pedestrian Overpasses Bridge can be design environmental friendly especially in land uses.

\section{Design Method}

POBET require the boundary condition as pedestrian overpasses bridge. As structural design there is several ultimate condition for safety factor not less than 1,10 , service limit state with safety factor not less than 1,10 and working load with safety factor not less than 2,0. Designing of POBET is just using basic structural analysis that will be modeled as numerical modeling.

\section{Design Phase}

Buildings selection for pedestrian overpasses as POBET needs requirements easy to reach with the maximum distance from central activity or bus stop not less than 50 meters.

Regarding to dimension, POBET will considering about height clearances based on table II 
TABLE II

POBET CLEARANCES HEIGHT [16]

\begin{tabular}{|c|c|c|}
\hline $\begin{array}{l}\text { Type of } \\
\text { Traffic }\end{array}$ & $\begin{array}{l}\text { Minimum Clearance } \\
\text { Height (meter) }\end{array}$ & $\begin{array}{c}\text { From the bottom of } \\
\text { Girder to }\end{array}$ \\
\hline $\begin{array}{l}\text { Road } \\
\text { - Passed by } \\
\text { Bus } \\
\text { - Not passed } \\
\text { by bus } \\
\end{array}$ & $\begin{array}{l}5,10 \\
4,60\end{array}$ & Pavement surface \\
\hline Railway & 6,50 & Top of rail \\
\hline
\end{tabular}

Minimum width of POBET is about 2,0 meter with the hedge with clearance for maintenance and any architectural attribute such billboard or plant.

Based on FEMA P646 [3] POBET as vertical evacuation (VE) need to consider about travel time (remaining time from tsunami early warning to arrival time of tsunami) and run up of tsunami. Then, routes to VE ease to access with clear sign. There is consideration as mentioned below,

\section{Early warning, Travel Time and Spacing VE}

Early warning time is about the sign aftershock to indicate the earthquake have a potential of tsunami. It takes 5 - 10 minutes after tremor. Based on inundation map of Padang City, it takes 20 minute for tsunami arrival time to reach the shoreline [11] Consideration must given to the time tae for designated occupants to reach refuge. To determine the maximum spacing of tsunami vertical evacuation structures, the critical parameters are warning time and ambulatory capability of the surrounding community. The average, healthy person can walk approximately $1,5 \mathrm{~km} /$ hours (FEMA, 2008). Assuming a 20 minute warning time associate with far-sourcegenerated tsunami, VE structures would need to be located a maximum of 500 meter from any given starting point.

\section{Ingress and vertical circulation}

Tsunami vertical evacuation structures should be spaced such that people will have adequate time not only to reach the structure, but to enter and move within the structure to areas of refuge that are located above the anticipated tsunami inundation elevation.

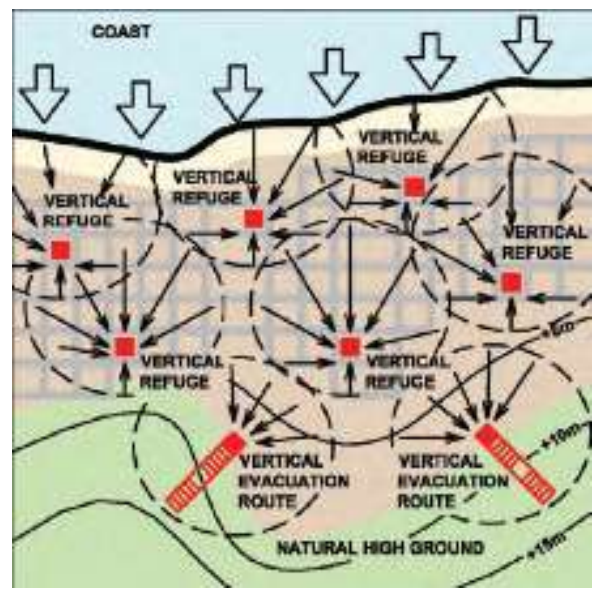

Fig.4. Vertical evacuation refugee location considering travel distance, evacuation behavior and natural occurring high ground. Arrow show anticipated vertical evacuation routes. (FEMA, 2008)

\section{Consideration of buildings hazard}

Special hazard in the vicinity of each buildings should be considered in locating vertical evacuation structures. Potential buildings hazards include breaking waves, source of large water bone debris and sources of waterborne hazardous material. When possible, vertical evacuation structures should be located away from potential hazards that could result in additional damage to the structure and reduce for safety occupants.

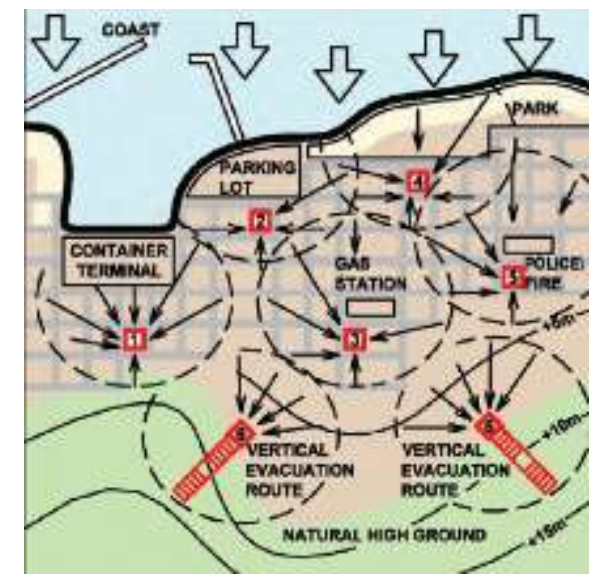

Fig.5. Buildings Hazards adjacent to vertical evacuation structures (numbered location). Arrows show anticipated vertical evacuation routes (FEMA, 2008)

\section{Sizing Consideration}

Sizing of vertical evacuation structure depends on the intended number of occupant, the type of occupancy, and the duration of occupancy. The number of occupants will depend on the surrounding 
population and the spacing and number of vertical evacuation structures located in the area. Duration of occupancy will depend on the nature of the hazard and the intended function of the facility.

\section{Service duration}

A vertical evacuation structure is typically intended to provide a temporary place of refuge during a tsunami event. While tsunami is generally considered to be short-duration events, tsunami includes several cycles of waves. The potential for abnormal high tides and coastal flooding can last as long as 24 hours.

\section{Elevation Considerations}

In order to serve effectively as a vertical evacuation structure, It is essential that the area o $f$ refugee be located well above well above the maximum tsunami inundation level anticipated at the buildings. Determination of a suitable elevation for tsunami run up elevation, possible splash-up during impact of tsunami waves, and the anxiety level of evacuees seeking refuge in the structure. Recommended minimum refuge elevation is the maximum anticipated tsunami run up elevation, plus $30 \%$, plus 3 meters.

\section{Size of Vertical Evacuation Structures}

Given the number and spacing of vertical evacuation structures and the population in a given community, the minimum size can be determined based on square footage recommendation for the intended duration and type of occupancy. Consideration of other functional needs, such restroom, supplies, communication and emergency power, should be added to overall size of the structure. In equation is shown below,

$$
H_{V E}=1.3 H_{\text {Tsunami }}+3 \text { meter }
$$

\section{Cost Estimation}

Cost estimation has various accuracy of cost prediction. Accuracy of cost estimation is linear with detailing of breakdown work of planning. Accuracy of cost estimation would be considered based on table (KoNTeKS, 2015) below,
TABLE III

ACCURACY OF COST ESTIMATION

\begin{tabular}{|l|c|}
\hline \multicolumn{1}{|c|}{ Type of estimation } & $\begin{array}{c}\text { Percentage of } \\
\text { Accuracy }\end{array}$ \\
\hline Conceptual Design & $\pm 15-20 \%$ \\
\hline Feasibility Study & $\pm 10-15 \%$ \\
\hline Engineering Design & $\pm 5-10 \%$ \\
\hline Construction & $\pm 5 \%$ \\
\hline Change Order & - \\
\hline
\end{tabular}

Then, the framework the process in conceptual design of POBET would be work on process based on flowchart below,

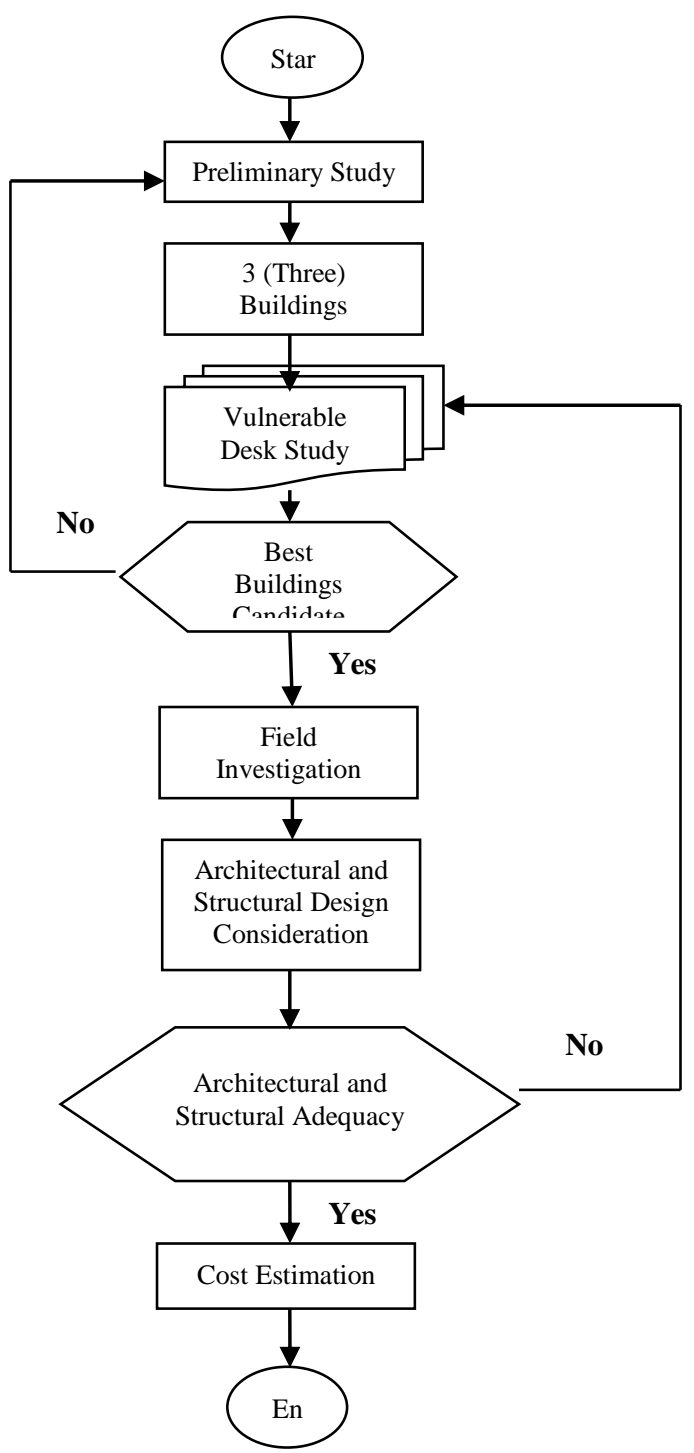

Fig.6 Algorithm of POBET Conceptual Design

\section{ANALYSIS AND RESULT}

Regarding to preliminary study for POBET, three buildings candidates for it has been established based on vulnerability parameters in disaster aspect, design and function. Three buildings candidate investigated 
based on vulnerability parametric index on Table I to observe and measure how high the buildings as prone area and necessity the community for vertical evacuation. Table IV show vulnerable index for each buildings.

1. Bagindo Azis Chan intersection, South Padang District ( Location I)

2. Jati Intersection, East Padang District (Location II)

3. Tunggul Hitam Intersection, North Padang District (Location III)

TABLE IV

POBET BUILDINGS CANDIDATE VULNERALBILITY INDEX

\begin{tabular}{|c|c|c|c|c|c|c|c|c|c|c|c|c|c|c|c|c|c|}
\hline $\begin{array}{c}\text { Loc } \\
\text { atio } \\
\mathbf{n}\end{array}$ & $\begin{array}{c}\mathbf{S} \\
\mathbf{u} \\
\mathbf{m}\end{array}$ & $\mathbf{A}$ & $\mathbf{B}$ & $\mathbf{C}$ & $\mathbf{D}$ & $\mathbf{E}$ & $\mathbf{F}$ & $\mathbf{G}$ & $\mathbf{H}$ & $\mathbf{I}$ & $\mathbf{J}$ & $\mathbf{K}$ & $\mathbf{L}$ & $\mathbf{M}$ & $\mathbf{N}$ & $\mathbf{0}$ & $\mathbf{P}$ \\
\hline I & 61 & 2 & 3 & 4 & 2 & 5 & 3 & 3 & 9 & 3 & 2 & 3 & 1 & 5 & 5 & 3 & 8 \\
\hline $\mathrm{II}$ & 71 & 2 & 3 & 5 & 2 & 5 & 1 & 5 & 1 & 5 & 2 & 3 & 1 & 5 & 5 & 2 & 1 \\
0 \\
\hline III & 64 & 2 & 3 & 4 & 2 & 5 & 3 & 3 & 9 & 5 & 1 & 1 & 1 & 5 & 5 & 5 & 1 \\
0
\end{tabular}

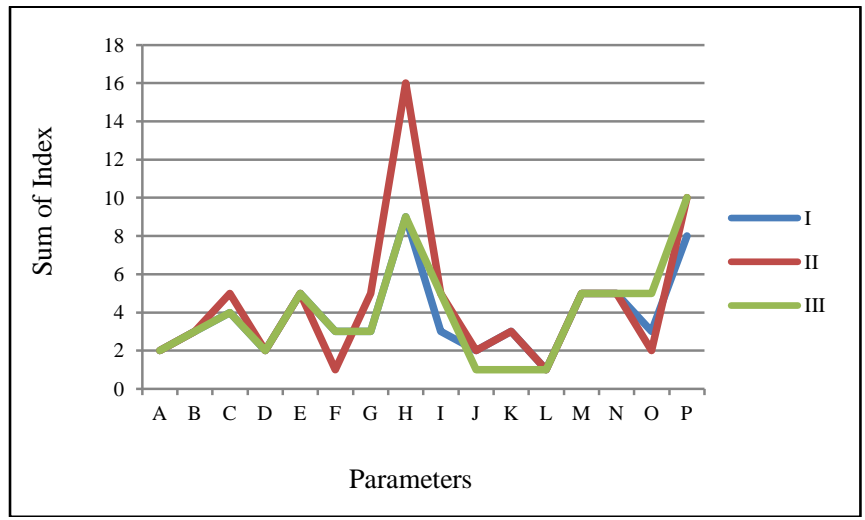

Fig.7. POBET Buildings Candidate Vulneralbility Index

Note of Parameters:
A = Tsunami Innundation Distance
$\mathrm{B}=$ Shorline Distance
C = Riverside Distance
D = Tsunami Inundation Height
$\mathrm{E} \quad=$ Peoples District Density
$\mathrm{F} \quad=$ Male Density
$\mathrm{G} \quad=$ Female Density
$\mathrm{H}$ = Age Composition Density
$\mathrm{I}=$ Education Facilities
$\mathrm{J}=$ Religion Facilities
$\mathrm{K}=$ Health Facilities
$\mathrm{L} \quad=$ Other Facilities
$\mathrm{M}=$ Vertical Evacuation Buildings Distance

$\mathrm{N}=$ Horizontal Evacuation Buildings Distance

$\mathrm{O}=$ Evacuation Travel Time

$\mathrm{P} \quad=$ Evacuation Routes Capacity

Result of indexation from three buildings candidate, it show sum of index based on tsunami vulneralbility for POBET. Location I at Bagindo Azis Chan intersection South Padang District have 61 point, location II at Jati intersection - East Padang District have 72 point, and location III at Tunggul Hitam intersection - North Padang District have 64 point. According to these result, the most vulnerable to be design as POBET prototype is location II at Jati intersection - North Padang District.

TABLE IV

BUILDINGS LOCATION I FOR POBET

\begin{tabular}{|l|l|}
\hline Buildings Plan \\
\hline Location & Jati intersection \\
\hline Village & Jati Baru \\
\hline District & East Padang \\
\hline Coordinates & \\
\hline North & $0^{\circ} 56^{\prime} 3,35^{\prime \prime} S$ \\
\hline South & $100^{\circ} 21^{\prime} 40,54 " \mathrm{~N}$ \\
\hline
\end{tabular}

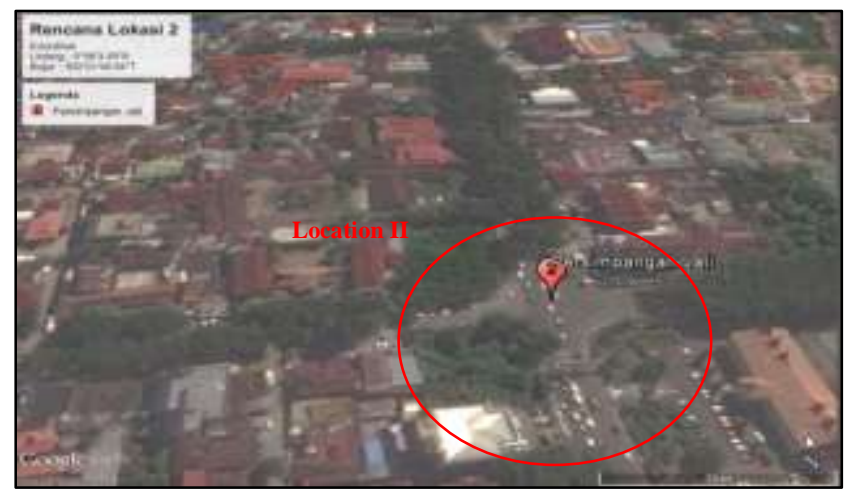

Fig.8. Location I for POBET Buildings Candidate from Satelite Image (Google Map, 2017)

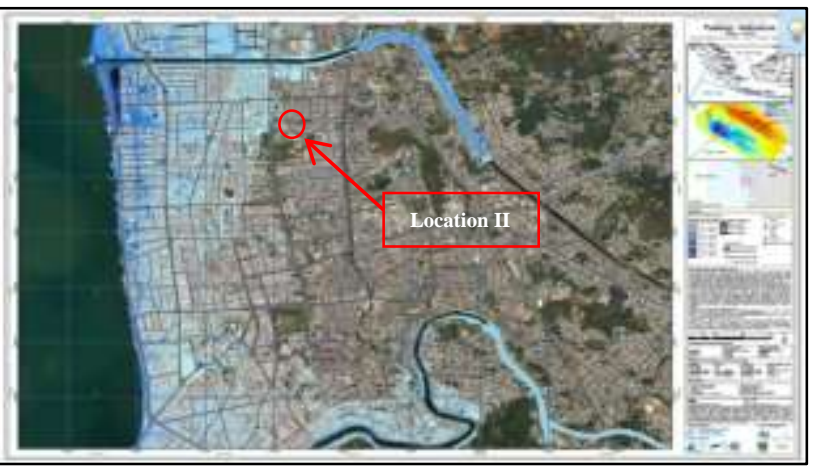

Fig.9 Tsunami Inundation Map (Last Mile, 2005) 
Regarding to run up estimated by tsunami inundation map (last mile, 2005), Jati Baru intersection is inundated $0.00 \mathrm{~m}-0.10 \mathrm{~m}$. The level of vuleralbility of location II is less vulnerable from tsunami effect. It recommended for evacution buildings and have less affected from first waves force of tsunami that can destruct and generate numerous debris for evacution infrastructure.

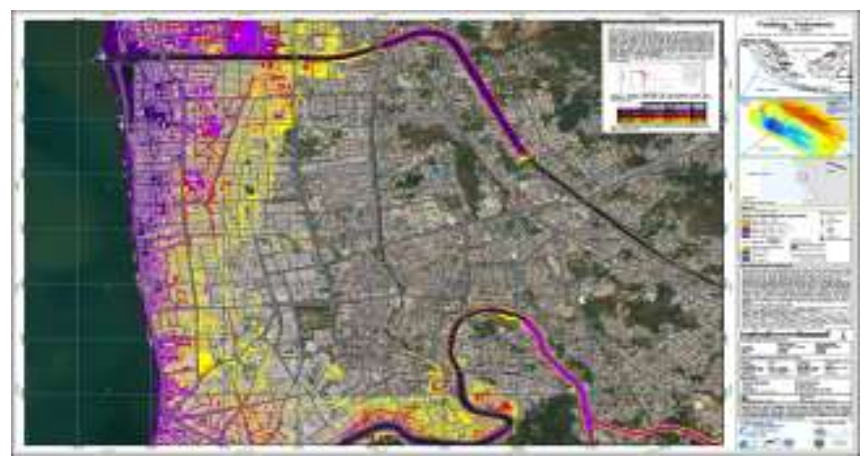

Fig.10 Tsunami Energy Specification Map (Last Mile, 2005)

Based on stability and human manuverability is exposed water flow (RESDCAM 2000), hydrodinamic of specific energy to clarify vulneralbility zone and risk in Padang, it is projecter in raster 5 that showed potential energy and kinetic generated by water flow. In fig. 8 show the maximum of specific energy during inundation. Fig. 8 indicate the result of physical test for stability and human manuverability in various expose in sealed water tank [6]. It's result show $0.64 \mathrm{~m}^{2} / \mathrm{s}$ and $1.26 \mathrm{~m}^{2} / \mathrm{s}$ where human body will lost the satbility in these condition. Based on this result, the water depth (d) 1,0 meter and flow velocity (v) $1,0 \mathrm{~m} / \mathrm{sec}$ for clarification. Others clarification is choosen as subjectif parametric. Value $d$ and $v$ are shown in table $\mathrm{VI}$

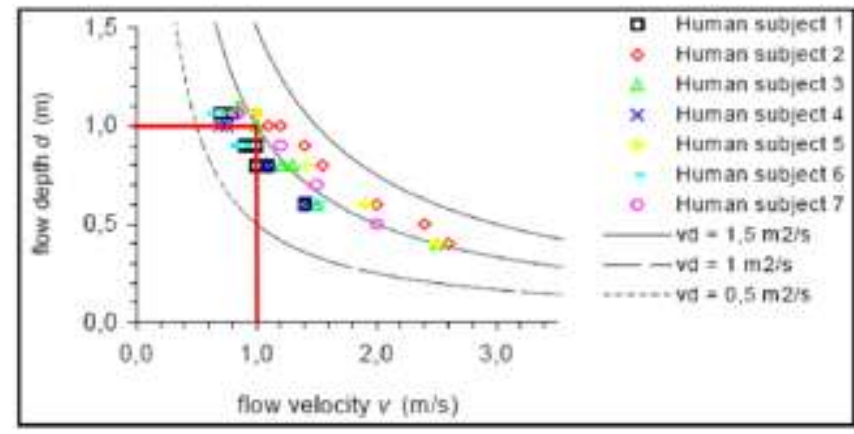

Fig.11 Decreasing human stability and manuverability is exposed water flow (RESDCAM 2000)
TABLE V

LEVEL OF VULNERABILITY FOR HUMAN STABILITY AND MANUVERABILITY FROM WATER FLOW

\begin{tabular}{|l|c|c|c|}
\hline \multirow{2}{*}{$\begin{array}{c}\text { Level of } \\
\text { Risk }\end{array}$} & Water Depth & Flow Velocity & $\mathrm{E}_{\text {spec }}$ \\
\cline { 2 - 4 } & $(\mathrm{m})$ & $(\mathrm{m} / \mathrm{sec})$ & $(\mathrm{m})$ \\
\hline Very High & $>3.00$ & $>2.00$ & $>3.31$ \\
\hline High & $1.50-3.00$ & $1.50-2.50$ & $1.61-3.31$ \\
\hline Severe & $1.00-1.50$ & $1.00-1.50$ & $1.05-1.61$ \\
\hline Medium & $0.75-1.00$ & $0.75-1.00$ & $0.78-1.05$ \\
\hline Low & $<0.75$ & $<0.75$ & $<0.78$ \\
\hline
\end{tabular}

In designing of POBET, accessibility is the highest priotity for evacuee to reach top of the structure. Based on vertical evacation guidelines (cabinet office , 2005). It's indicate acendance/ decendance velocity from evacuation buildings $(P)$. By using Table VI calaculate $\mathrm{P} 1=0.88-1.29 \mathrm{~m} / \mathrm{sec}$ (from the code $1,00 \mathrm{~m} / \mathrm{sec}$ ) and $\mathrm{P} 2=0.21 \mathrm{~m} / \mathrm{sec}$

TABLE IV

GUIDELINES FOR SPECIFICATION OF WALKING SPACE (CABINET OFFICE JAPAN, 2005)

\begin{tabular}{|c|c|}
\hline Case & Condition \\
\hline \multirow[b]{3}{*}{$\begin{array}{l}\text { Walking under } \\
\text { normal condition (P1) }\end{array}$} & $\begin{array}{l}\text { Elderly person walking } \\
\text { unassisted: } \mathbf{1 . 3} \mathrm{m} / \mathrm{sec}\end{array}$ \\
\hline & $\begin{array}{l}\text { Crowd walking space: } 0.88 \text { to } \\
1.29 \mathrm{~m} / \mathrm{sec} \text { (sighted people) }\end{array}$ \\
\hline & $\begin{array}{l}\text { Handicapped persons walking } \\
\text { space: } 0.91 \mathrm{~m} / \mathrm{sec} \text { (average) } \\
\text { ( in the case of a handicapped } \\
\text { person who uses a wheel } \\
\text { chair) }\end{array}$ \\
\hline Ascending/decending & $\begin{array}{l}\text { Speed for ascent/descent of } \\
\text { stairs (elderly person) } \mathbf{0 . 2 1} \\
\mathbf{m} / \mathbf{s e c}\end{array}$ \\
\hline
\end{tabular}

So, it is calculated

(t2) $\quad=\frac{H \max }{\mathrm{P} 2}=\frac{9 \mathrm{~m}}{0,21 \mathrm{~m} / \mathrm{s}}=42,86$ second

Evacuation distance $(L 1)$ measured by

$L 1=P 1 \times T-t 1-t 2$

$=1,0 \mathrm{~m} / \mathrm{sec} \times 1800 \mathrm{sec}-1200 \mathrm{sec}-42,86 \mathrm{sec}$

$=557,14 \mathrm{~m}$

Accomodated distance (L2) measured by

$$
\begin{gathered}
L 2=\sqrt{\frac{\left(\frac{\text { Expected Capacity }}{\text { People Density }}\right)}{3,14}} \times 4=\sqrt{\frac{\left(\frac{100 \text { orang }}{0,06540 \text { orang } / m^{2}}\right)}{3,14}} \times 4 \\
=88,268 \mathrm{~m}
\end{gathered}
$$




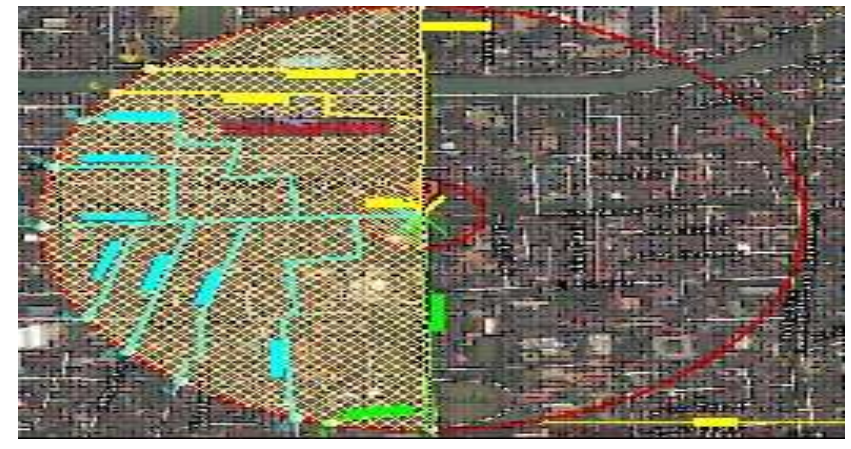

Fig.12 Coverage area and direction of evacuee movement for location II

Number of Community evacuation movement routes based coverage area (directon of movement evacuees) for location II is divided into three assembly point in different routes (Fig.12)

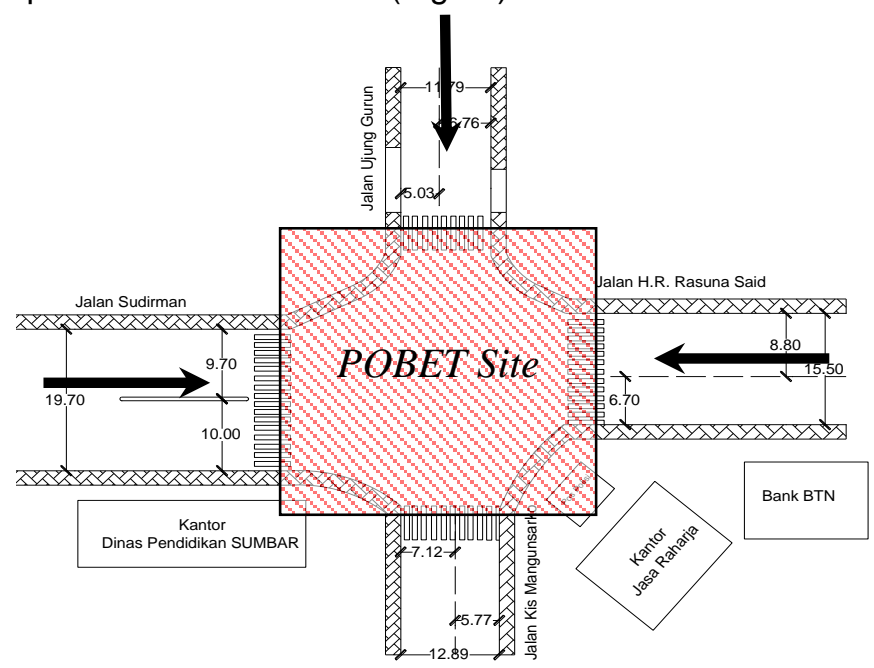

Fig.13 Intersection of Jati Geometric and Direction of Evacuation

Based on the parametrics index of tsunami vulmeralbility, accessibility, achievability, and the code of pedestrian overpasses bridge design. POBET will be have preliminary specification based on table

TABLE VI

PRELIMINARY SPECIFICATION OF POBET

\begin{tabular}{|c|c|c|c|c|}
\hline Specs. & \multicolumn{4}{|c|}{ Preliminary } \\
\hline $\begin{array}{l}\text { Shape } \\
\text { and Type }\end{array}$ & \multicolumn{4}{|c|}{$\begin{array}{l}\text { Intersection Pedestrian Overpasses Bridge for Vertical } \\
\text { Evacuation }\end{array}$} \\
\hline \multirow{6}{*}{ Dimension } & $\begin{array}{l}\text { Struct. } \\
\text { Height }\end{array}$ & \multicolumn{3}{|c|}{$\begin{array}{l}15.9 \text { ( the menimum Height) based on clearance } \\
\text { and inundation height }\end{array}$} \\
\hline & \multirow{5}{*}{ Area } & \multicolumn{3}{|c|}{$\begin{array}{l}\text { Based on fig.... is calculated the estimation of } \\
\text { area for POBET }\end{array}$} \\
\hline & & Stories & Function & Area \\
\hline & & Satu (1) & Pedestrian Cross & $587 \mathrm{~m}^{2}$ \\
\hline & & Dua (2) & Shelter & $587 \mathrm{~m}^{2}$ \\
\hline & & Tiga (3) & Shelter & $587 \mathrm{~m}^{2}$ \\
\hline Material & \multicolumn{4}{|c|}{ Minimum streght of material is about $f^{\prime} \mathrm{c}=20 \mathrm{Mpa}$} \\
\hline
\end{tabular}

In terms of architectural and functional of POBET. It will be use as alternative vertical evacuation in Padang
City especially in East Padang District that will accomodate $25 \%$ for community to evacuate from tsunami. It also use as public area in daily life as pedestrian cross (meeting point) in 1st story, Food Court in 2nd Story and Sport area in 3rd Story. This design is shown at fig. 14, 15 and 16 .

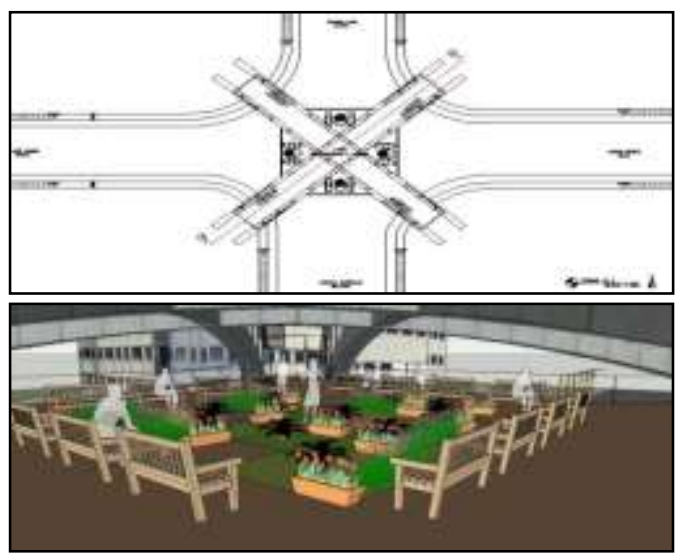

Fig.14 1st story of POBETas pedestrian cross and meeting point

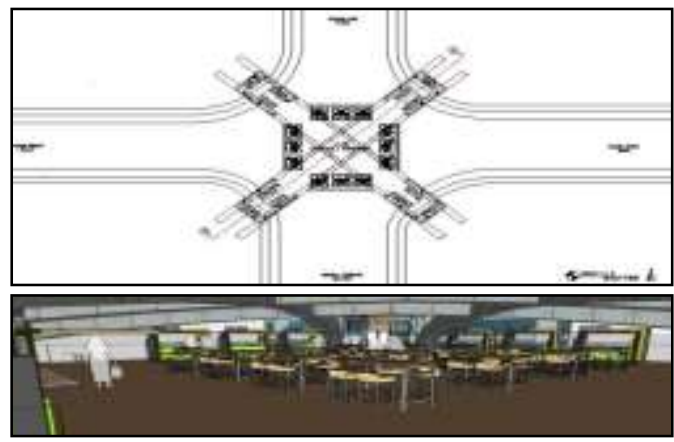

Fig.15 2nd story of POBETas Shelter + Food Court

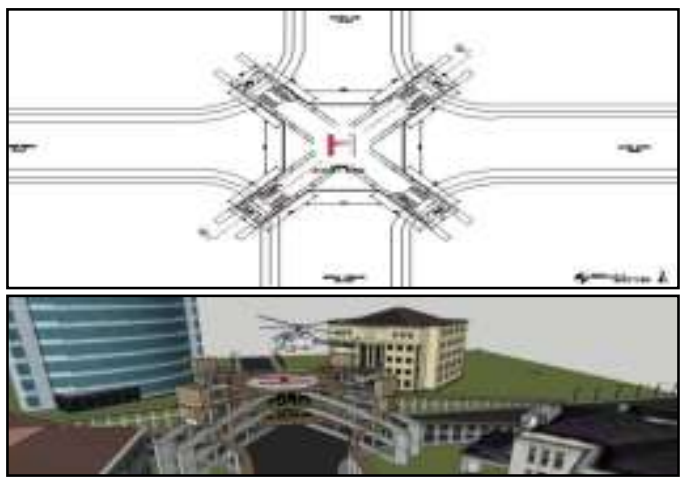

Fig.16 3rd story of POBET as Sheleter + Sport Arena

\section{CONCLUSIONS}

As conceptual design for vertical evacuation, POBET is adequate as an alternative shelter structure to solve the horizontal evcuation bottle neck. It has multi-functional shelter based on vulneralbility 
parametric index, pedestrian bridge code, structural adequacy and preliminary structure. POBET can accomodate community and traffic user that would not evacuate to inland. This conceptual design will be observed and studied for detailed engineering design as prototype vertical evacuation in Padang City - West Sumatra, Indonesia.

\section{NOMENCLATURE}

$\begin{array}{lll}H_{V E} & \text { Size of Vertical Structures } & \mathrm{m} \\ H_{\text {Tsunami }} & \text { Run up elevation } & \mathrm{m} \\ t 1 & \text { time for ascending } & \mathrm{sec} \\ t 2 & \text { time fo descending } & \mathrm{sec} \\ P 1 & \text { Velocity ascending/decending } & \mathrm{m} / \mathrm{s} \\ L 1 & \text { Evacuation distance } & \mathrm{m} \\ L 2 & \text { Accomodate distance } & \mathrm{m}\end{array}$

\section{REFERENCES}

1. Syukri, Andi and M. Fajri, transformation natural catastrophe potential index due to regional planning, 3rd Institute Regional Science Association Symposium, Padang, 2011

2. Last Mile, Padang Inundation Map, Padang 2010

3. Applied Technology Council, Guidelines for Design of Structure for Vertical Evacuation from Tsunamis, FEMAP646, June 2008

4. V. Cedillos, N. Canney, G. Deierlein, S. Henderson, F. Ismail, A. Syukri, J. Toth, K. Wood, An Evaluation of Infrastructure for Tsunami Evacuation in Padang, West Sumatra, Indonesia. 4th Tsunami International Symposium, Toronto Canada, 2011

5. Director General for Disaster Management, Cabinet Office Japan, Tsunami Mitigation Guidelines for Evacuation Buildings, June 2005

6. T. Karvonen, A. Hepojoki, J. Kotola H.-K. Huhta: RESCDAM - The use of physical models in dambreak flood analysis, Final report of Helsinki University of Technology, 2000.

7. K.I.Aji, Characteristic analysis and signal intersection performance, Naskah publikasi tugas akhir Vol.2 Fakultas teknik Sipil, Universitas Muhammadiyah Surakarta, 1 - 15, 2013.

8. Z. Alhadi, Public Evcuation route and location availability for earthquake and tsunami catastrophy in Padang City (Disaster Management Study). Humanus Vol XIII no. 1, 6 8

9. F.D. Ashar, The Analysis of tsunami vertical shelter in Padang City. 4th International Conference on Building Resiliences, Salford Quays, United Kingdom 916 - 923, 2004

10. BMKG. Earthquake and Tsunami Vulnerable Zone. Meteorologi dan Geofisika Vol 11 No.2. 2010

11. BNPB, Padang Evacuation Map. 2010

12. BPS, Katalog BPS Padang Barat dalam Angka. BPS Kota Padang. 2015

13. D. Natawijaya. Sejarah Kegempaan di Indoneisa (netonotics the sumatran faults). Journal of Geophysical research 105. 2000

14. Harismani. Disaster Risk Analysis of Padang City, $62-65,2008$

15. Muhari, A.S. Performance evaluation of Pedestrian bridge as vertical evacuation buildings during the 2011 tsunami in Japan. Journal of Natural Disaster Sciences, Volume 34 Number 1, 79-81.2012

16. Departemen Pekerjaan PU Direktorat Jenderal Bian Marga. Tata Cara Penyebrangan Orang di Kawasan Perkotaan No.027 T/Bt/1995. Jakarta 1995

17. Standar Nasional Indonesia. Perencanaan Struktur Beton untuk Jembatan. SNI T-12-2004. Jakarta 2004

18. B. Tucker. Prototype tsunami evacuation park in Padang, West Sumatra, Indonesia. GeoHazards International 1-41. 2013 